Elsevier required licence: (c) $<2018>$. This manuscript version is made available under the CC-BY-NC-ND 4.0 license http://creativecommons.org/licenses/bync-nd/4.0/ 
Title: Moving beyond financial value in seafood commodity chains

Authors: Michael Fabinyi ${ }^{\mathrm{a}}$, Wolfram Dressler ${ }^{\mathrm{b}}$, and Michael Pido ${ }^{\mathrm{c}}$.

a Corresponding author: University of Technology Sydney, 235 Jones st, NSW 2007. Email: michael.fabinyi@uts.edu.au. Phone: (+61 2) 95142308

b School of Geography, University of Melbourne, Parkville 3052, VIC, Australia. Email: wolfram.dressler@unimelb.edu.au. Phone: (+61) 402761208.

c Center for Strategic Policy and Governance, Palawan State University, Tiniguiban Heights, 5300 Puerto Princesa City, Palawan, Philippines. Email: m.pido@psu.palawan.edu.ph Phone: $(+6348) 4340109$

\section{Acknowledgements}

This research for this paper was supported by an Australian Research Council Discovery Grant (DP140101055). 


\title{
Moving beyond financial value in seafood commodity chains
}

\author{
Abstract \\ Emerging forms of governance and many academic analyses of seafood commodity chains \\ currently have a strong focus on financial value, transmitted in a linear 'vertical' fashion from \\ fisher, through traders to eventual consumers. This Brief Communication argues that the \\ social dimensions of value must be given explicit attention in analysis if seafood commodity \\ chains are to be made more equitable and sustainable in changing governance contexts. The \\ paper draws on evidence from selected seafood commodity chains across the Philippines, \\ demonstrating the range of co-produced social values that are of equal or greater significance \\ than financial value. Fishers, traders and consumers, all generate multiple social values that \\ shape the nature and outcomes of seafood commodity chains. In contrast to forms of fisheries \\ governance that focus exclusively on financial or ecological values, the paper suggests that \\ integrating multiple social values into the governance of seafood commodity chains, as well \\ as at the site of production, should become a core focus of research and policy.
}

KEYWORDS: seafood trade; commodity chains; value chains; Philippines

\section{Introduction}

Increasing demand for seafood has converged with social and economic changes in coastal sites of production to dramatically intensify seafood trade. In response, a growing academic literature has tried to examine the causes, natures and consequences of expanding seafood trade [1-4], with a growing subset of this research analysing fisheries trade in terms of "value chains' or 'commodity chains' [5-8]. Commodity chains are a distinct field of study, with a wide variety of perspectives, approaches and terminologies informed by different disciplinary and epistemological underpinnings [9-11]. However, the approach taken to analyse seafood 
commodity chains has so far mostly followed a fairly narrow subset of commodity chain approaches. Such analyses have a strong focus on financial value, transmitted in a linear 'vertical' fashion from fisher, through traders, exporters and importers through to eventual consumers. The emphasis in such studies is frequently on understanding how financial value is distributed within the commodity chain, and on investigating opportunities for actors to upgrade their position in the commodity chain in order to obtain greater financial value. For example, a recent major project by the FAO on fishery and aquaculture value chains focused largely on economic upgrading and prices [12].

Environmental governance practices have also shifted from a conventional focus on placebased measures (quotas, gear restrictions, seasonal closures, protected areas etc.) to a focus on seafood trade and financial value through market-based tools such as certification and ecolabelling, catch documentation and traceability (CDT) [13]. However, prioritising value as financial in such analysis and governance practice has largely come at the expense of understanding the contextual, relational production of varied social values along seafood commodity chains. This has particular implications for the coastal poor who sit at the extractive end of commodity chains, and who are most vulnerable from changing governance approaches as well as dwindling fish stocks.

A growing field of social research has highlighted the importance of multiple values in smallscale fisheries. Literature on 'interactive fisheries governance' [14], for example, has shown how effective governance needs to acknowledge and incorporate multiple, often conflicting values among different groups. In particular, scholars have used the concept of wellbeing as a way to frame the multiple values affiliated with small-scale fisheries, arguing that wellbeing goes well beyond financial values to include material, subjective and relational dimensions [15-16]. However, while emerging social research on seafood commodity chains is expanding rapidly [e.g. 11, 17] there remains less emphasis on explicitly integrating the idea 
of multiple values into work on seafood commodity chains. This Brief Communication therefore stresses that not only do multiple forms of value matter along seafood commodity chains over time, but that they are also produced in a relational manner and must be understood in this context. Emphasising the importance of historical and social perspectives on commodity chains, the paper argues that the relational dimensions of value must be given explicit attention in analysis if value chains are to be rendered more equitable and sustainable in changing governance contexts.

We argue that both commodity chain studies of fisheries and market-oriented governance practices could benefit from a broader and more contextual engagement with the idea of value. It specifically shows the significance of taking a broader view of 'value' and investigating how such values are changing in different contexts across scales and geographies. Rather than using the commodity chain as a formal tool with specific quantitative assessments, the paper uses the notion as a heuristic lens to more deeply contextualise and rethink the complex character of value production along the chain. The paper does so by drawing on notions of value from selected seafood commodity chains across the Philippines. The aim is to highlight how the commodity chain transmits not only financial value along the chain, but also expresses - as commodities move in and out of different social contexts, and across varied biophysical locations [18] - a range of other values (sociocultural, political or otherwise) that are as significant as financial value but in different ways. Anthropologists, for example, have long argued that economic exchange practices are always intertwined within social relationships that give them meaning [19-20]. If, as Appadurai [20] noted, all commodities have 'social lives' intertwined with both capitalist and non-capitalist relations, meanings and practices, then because these vary over time and space, the production of value within and between things and peoples is contingent on specific histories, ecologies, peoples and places [21: 15]. The varied values of seafood in trade are therefore 
'produced and related to or embedded within the larger sets of social relations' along value chains [22, 20: 15].

The Philippines is a site of particular significance for the study of seafood commodity chains for several reasons, including: its heavy reliance on fisheries for the livelihoods of millions of coastal poor; its role as a globally significant producer of fishery products [23]; the high number of governance arrangements pioneered and implemented in the country [24]; the exceptionally high marine biodiversity [25]; and the strong threats to the marine environment [26]. Examples are drawn from specific value chains in the published literature.

\section{Fishers}

At the extractive end of commodity chains in the Philippines, poor coastal fishers' 'transactional' engagement is most often represented by a figure of financial value, such as the beach price obtained by the fisher [7], or to the proportion of overall financial value obtained by the fisher [27]. From this perspective, fishers become closely identified with the financial aspects of seafood trade, and can be labelled as 'price-takers' [8]. These depictions are not inaccurate - fishers at the extractive end of value chains across the country face a range of significant challenges to generate income, many of which are site and region specific. A lack of adequate post-harvest facilities, for example, means fishers struggle to add financial value to their products and remain subject to the prices offered by traders.

However, such a focus on direct financial value reduces the complexity of different roles, values and ideas involved in the act of fishing. At a broader level, for example, poor fishers at the 'extractive end' see fishing not simply in terms of 'Peso value' but also relative to the idea of livelihood (hanapbuhay) and food - indirectly through sales of fish but also through 
the 'use-value' of fish in terms of direct consumption by fishers. Often fishers will trade the best-quality fish for income and rice, and eat the cheaper, smaller varieties [28]. From a socio-cultural perspective, the value of fisheries production can also be valued through its linkages to reciprocity and sharing, such as how it can mediate relationships between fishers and other community members [29]. Russell and Alexander [30], for example, highlight the pressure on commercial fishers to give away portions of their catch among different members of the community. Giving away fish can be emblematic of other values such as masculinity, as in many fishing communities generosity and fishing ability are significant markers of a gendered social status [31]. Fishing can also be valued in other non-economic ways: fishers have a variety of socio-cultural motives for fishing, such as independence [32].

Fishers also experience changing values that affect how they participate in seafood commodity chains. The mobulid ray (Mobulidae) fishery in the Bohol Sea, for example, has changed dramatically over the course of several decades. Originally, this fishery was based around the capture of rays, for the local consumption of meat. Since the 1980s, however, the mobulid fishery has transformed to one based around the export of gill plates, ultimately to China. It has therefore shifted from a local fishery commodity chain where the relative emphasis was on the use value of food consumption for local households, to one where the relative emphasis is almost completely now focused on a much more discrete exchange value, for the correspondingly discrete gill plates [33].

Issues of gender (and other social relations such as ethnicity) also factor into and strongly inform the production of social value at the extractive end of the commodity chain. In the fisheries sector, women's significant roles in the pre- and post- harvest sectors have been well-established, as well as their role in gleaning [34-35]. Many of women's and children's labour contributions (e.g. gutting/cleaning/drying of fish, net mending, marketing) are 
relatively neglected in decision-making processes, and do not entitle them to the same rights as male fishers [36]. Crucially, the capitalist relations of production and exchange that underpin commodity chains often also render invisible and unvalued the unpaid female labour of reproduction, child care and other domestic chores that allow male fishers to go out to sea.

\section{Labour and trading}

Beyond the extraction of fish, individual roles and working conditions are changing, and can intensify along the chain. Small-scale capture fisheries, with smaller capital and crews, tend to operate as petty commodity producers, with kin relations playing significant roles in employment and also in terms of understandings of how fishing success is valued [37]. By contrast, the large-scale commercial fisheries that developed in the Philippines through the twentieth century [38] tend to operate on principles of firms or corporations, with contracts, wages and non-personalised crew recruitment [30]. Similarly, as large-scale aquaculture becomes more prominent across the Philippines (e.g. for milkfish, tilapia and prawns), fishers who transition to this work tend to become more subject to the broader financial goals and values of the company. The transition from capture fisheries to aquaculture also has potentially negative consequences for nutritional values of fish for consumers [39].

Multiple values in seafood commodity chains are also expressed through the diverse roles of traders. Traders are often emphasised to be the actors who extract the largest portions of financial value in fisheries commodity chains $[7,27,40]$ and are sometimes consequently labelled as exploitative. Traders do indeed obtain greater proportions of financial value in many seafood commodity chains, and incidents of extreme exploitation have been welldocumented, for example in the notorious muro-ami fishery of the 1980s [38], as well as more recent concerns over forced labour [41]. Yet the role of traders also generates 
significant value for the broader livelihoods of poor fishers. In particular, they frequently provide credit to fishers in an environment where other forms of credit (e.g. from the government or private banking institutions) are inaccessible because of stringent lending requirements, or are only offered at very high interest rates. For many fishers, the credit offered by traders is an important means to begin a new fishing enterprise. In the rural Philippines, such relationships are typically not confined to the provision of credit for fishing, but can extend as a social safety net during periods of financial hardship. For example, fishers in the live reef fish trade in Palawan frequently request loans from their buyers for rice and other essential purchases if there is bad weather [42]. Importantly, the relationships between fishers and traders in the Philippines are also embedded in local cultural values such as pity (maawa) for the poor, a 'right to survive' [43], pakikisama (the ability to get along with people) and utang na loob (debt of gratitude).

\section{Consumption}

At the point of consumption, different social values in varied geographies also heavily influence the nature of the chain. Increasingly, consumer preferences for sustainably managed fish in locations such as Europe influence the ways in which fish for some export markets must be caught, subsequently informing the development of fisheries regulations in source countries such as the Philippines [44]. However, such values vary significantly among end markets - in China, for example, live groupers are valued not in terms of their environmental sustainability, but by their signification of social status and 'face' (mianzi) for guests at banquets [45]. These Chinese social values have meant that fishers in the Philippines target fish of particular size and colour, and has meant that trade has expanded rapidly with limited regulations for environmental sustainability [42]. The preference is usually for a plate-size red coral grouper, which is a sub-adult or has not yet spawned. Such 
qualitatively different values about the consumption of fish therefore fundamentally shape the ways in which many seafood commodity chains develop over time. From this perspective, value is not simply a financial quantity to be identified and measured, but one which is fundamentally relational, and meaningful through its links with other ideas, processes and activities [16]. Seeing seafood commodity chains from this relational perspective has implications for how governance of value chains is perceived.

\section{Governance}

In recent decades, conservation and ecological values have become increasingly prominent for the governance of seafood commodity chains in the Philippines. While a plethora of governance tools exist that include both state and non-state actors, CDT and certification are two linked tools associated with commodity chains that are rapidly growing in uptake and significance [46]. These market-based tools are designed to work with fisheries trade rather than against it. Certification such as that of the Marine Stewardship Council aims to more effectively regulate fisheries stocks by linking market actors such as traders and fishers to the idea of sustainable seafood, which commands a price premium in many markets. CDT is a fundamental component of certification that helps ensure the fish are legally caught and properly labelled. In such a way, market actors are supposed to become incentivised to participate in environmentally sustainable value chains, and so financial value can be generated while maintaining the ecological integrity of the fish stocks.

While certification has so far mostly been limited to fisheries in developed countries, steps towards certification (such as through Fisheries Improvement Projects and CDT programmes) are increasingly being applied in developing countries such as the Philippines. However, the ways in which small-scale fishers will be able to access the financial value gains associated with such market-oriented mechanisms, and the ways in which rights and equity will be 


\section{Recognising social values in seafood commodity chains}

In contrast, other emerging forms of fisheries governance and political approaches, which are not exclusively focused on financial and ecological value, have the potential to better account for multiple and changing values that reflect the context of people and places [49]. Firstly, research on wellbeing has strongly emphasised the need to understand multiple social values [16], and new methods elucidate ways to understand and incorporate the multiple values of fisheries along the commodity chain $[51,52,53]$. Secondly, human-rights approaches to fisheries governance are becoming more prominent, expressed through initiatives such as Fairtrade fisheries [54], the FAO Voluntary Guidelines for Small-Scale Fisheries [55], attention to gender mainstreaming in fisheries development projects, and calls for socially responsible seafood [56]. These human-rights based approaches that emphasise 'social upgrading' do not depend on states or markets alone, but instead involve greater roles for a wider range of actors including organised labour and civil society groups [57]. When coupled with each other, explicit attention to fishers' entitlement to a better income and safety nets (e.g., education, health costs) that facilitate greater opportunities for well-being might emerge at the extractive end of commodity chains.

Well-designed and targeted subsidies for small-scale fishers [58] have the potential to ensure an overall rise in basic minimum income that aligns with and supports explicit social values and aspirations at the household level (e.g., educational opportunities) [59]. This is, in effect, 
a 'subsidy for social values' at the poorest, most marginalized end of seafood commodity chains. From within and beyond the seafood industry, different income support plans can enable aspirational spaces for fishing households, with explicit insurance and gender provisions [59]. Such methods amount to bundling fisheries income subsidies and well-being concerns in order to create spaces that allow for the coastal poor to express and enact social values, needs and aspirations [60]. While any model of governance will involve simplifying local rural complexity in order to render technical solutions [61], how to ensure that approaches seeking to expand the capabilities of small-scale fishers should remain a core focus of both research and policy.

\section{References}

[1] Béné C, Lawton R, Allison EH. "Trade matters in the fight against poverty": narratives, perceptions, and (lack of) evidence in the case of fish trade in Africa. World Dev. 2010; 38(7):933-954.

[2] Béné C, Arthur R, Norbury H, Allison EH, Beveridge M, Bush S, Campling L, Leschen W, Little D, Squires D, Thilsted SH. Contribution of fisheries and aquaculture to food security and poverty reduction: assessing the current evidence. World Development 2016; 79:177-96.

[3] Gephart JA, Pace ML. Structure and evolution of the global seafood trade network. Environmental Research Letters 2015; 10:12.

[4] Crona B, Basurto X, Squires D, Gelcich S, Daw TM, Khan A, Havice E, Chomo V, Tröell M, Buchary EA, Allison EH. Towards a typology of interactions between small-scale fisheries and global seafood trade. Marine Policy 2016; 65:1-10. 
[5] Jacinto ER, Pomeroy RS. Developing markets for small-scale fisheries: utilizing the value chain approach. In: Pomeroy RS, Andrew NL (editors). Small-scale fisheries management: frameworks and approaches for the developing world. UK: CABI; 2011, pp160-77.

[6] Thyresson M, Crona B, Nyström M, de la Torre-Castro M, Jiddawi N. Tracing value chains to understand effects of trade on coral reef fish in Zanzibar, Tanzania. Marine Policy $2013 ; 38: 246-56$.

[7] Purcell S, Crona B, Lalavanua W, Eriksson H. Distribution of economic returns in smallscale fisheries for international markets: A value-chain analysis. Marine Policy 2017; 86:916.

[8] Rosales RM, Pomeroy R, Calabio IJ, Batong M, Cedo K, Escara N, Facunla V, Gulayan A, Narvadez M, Sarahadil M, Sobrevega MA. Value chain analysis and small-scale fisheries management. Marine Policy, 2017; 83:11-21.

[9] Bernstein H, Campling L. Commodity studies and commodity fetishism I: Trading down. Journal of Agrarian Change 2006; 6(2):239-64.

[10] Bair J. (editor). Frontiers of commodity chain research. Stanford, CA: Stanford University Press; 2009.

[11] Hamilton-Hart, N. and Stringer, C. Upgrading and exploitation in the fishing industry: Contributions of value chain analysis. Marine Policy 2016; 63:166-171.

[12] Bjørndal T, Child A, Lem A, Dey MM. Value chain dynamics and the small-scale sector: A summary of findings and policy recommendations for fisheries and aquaculture trade. Aquaculture Economics \& Management. 2015;19:148-73. 
[13] Bailey M, Bush SR, Miller A, Kochen M. The role of traceability in transforming seafood governance in the global South. Current Op Envi Sust 2016; 18:25-32.

[14] Jentoft S, Chuenpagdee R. Interactive governance for small-scale fisheries: Global Reflections. Dordrecht: Springer; 2015.

[15] Coulthard S, Johnson D, McGregor JA. Poverty, sustainability and human wellbeing: a social wellbeing approach to the global fisheries crisis. Global Environmental Change 2011; 21(2):453-63.

[16] Johnson D, Acott TG, Stacey N, Urquhart J (editors). Social Wellbeing and the Values of Small-scale Fisheries. Dordrecht: Springer; 2018.

[17] Belton B, Hossain MAR, Thilsted SH. Labour, identity and wellbeing in Bangladesh's dried fish value chains. In: Johnson D, Acott TG, Stacey N, Urquhart J (editors). Social Wellbeing and the Values of Small-scale Fisheries. Springer: Dordrecht; 2017.

[18] Foster RJ. Materializing the nation: Commodities, consumption, and media in Papua New Guinea. Bloomington: Indiana University Press; 2002.

[19] Mauss M. The gift: The form and reason for exchange in archaic societies. WW Norton \& Company: New York; 2000.

[20] Appadurai A (editor). The social life of things: Commodities in cultural perspective. Cambridge: Cambridge University Press; 1988.

[21] Nevins J, Peluso NL (editors). Taking Southeast Asia to market: Commodities, nature, and people in the neoliberal age. Ithaca: Cornell University Press; 2008.

[22] Cook I. Follow the thing: Papaya. Antipode 2004; 36(4):642-64. 
[23] Asian Development Bank (ADB). Economics of Fisheries and Aquaculture in the Coral Triangle. Asian Development Bank, Mandaluyong City, Philippines; 2014.

[24] Pomeroy R, Garces L, Pido M, Silvestre G. Ecosystem-based fisheries management in small-scale tropical marine fisheries: emerging models of governance arrangements in the Philippines. Marine Policy 2010; 34(2):298-308.

[25] Carpenter KE and Springer VG. The Center of the Center of Marine Shore Fish Biodiversity: The Philippine Islands. Environmental Biology of Fishes 2005; 72:467-480.

[26] Anticamara JA and Go KTB. Spatio-Temporal Declines in Philippine Fisheries and its Implications to Coastal Municipal Fishers' Catch and Income. Frontiers in Marine Science 2016; http://dx.doi.org/10.3389/fmars.2016.00021

[27] Trinidad AC, Albert J, Palma J, Matillano M, Boso D, Gaudiano JP, Manul J. Fisheries value retention in the coral triangle for highly traded commodities. In: Asian Development Bank. Economics of fisheries and aquaculture in the coral triangle. Manila: Asian Development Bank, 2014, p.107-140.

[28] Fabinyi M, Dressler W and Pido M. Fish, trade and food security: moving beyond the 'availability' discourse in marine conservation. Human Ecology 2017; 45(2):177-188.

[29] Segi S. "Losing at Sea, Winning on Land": A Case Study of Philippine Small-Scale and Industrial Fisher Resource Competition. Society and Natural Resources 2014; 27:1227-1241.

[30] Russell SD, Alexander RT. 'Of Beggars and Thieves: Customary Sharing of the Catch and Informal Sanctions in a Philippine Fishery.' In Durrenberger, EP and King, TD (eds), State and Community in Fisheries Management: Power, Policy and Practice. Westport (CT): Bergin \& Garvey; 2000. 
[31] Dumont J-P. Visayan Vignettes: Ethnographic Traces of a Philippine Island. Chicago: University of Chicago Press; 1992.

[32] Pollnac RB, Pomeroy RS, Harkes IHT. Fishery Policy and Job Satisfaction in Three Southeast Asian Fisheries. Ocean \& Coastal Management 2001; 44:531-44.

[33] Acebes JMV, Tull M. The History and Characteristics of the Mobulid Ray Fishery in the Bohol Sea, Philippines. PLoS ONE 2016; 11(8): e0161444.

https://doi.org/10.1371/journal.pone.0161444

[34] Weeratunge N, Snyder KA, Sze CP. Gleaner, fisher, trader, processor: understanding gendered employment in fisheries and aquaculture. Fish and Fisheries 2010 11(4):405-20.

[35] Kleiber D, Harris LM, Vincent AC. Gender and small-scale fisheries: a case for counting women and beyond. Fish and Fisheries 2015 16(4):547-62.

[36] Kruijssen F, Rajaratnam S, Choudhury A, McDougall C and Dalsgaard JPT. Gender in the farmed fish value chain of Bangladesh: A review of the evidence and development approaches. Penang, Malaysia: WorldFish. Program Brief: 2016-38; 2016.

[37] Russell SD, Poopetch M. Petty commodity fishermen in the inner Gulf of Thailand. Hum. Organ. 1990; 49(2):174-187.

[38] Butcher JG. The Closing of the Frontier: A History of the Marine Fisheries of Southeast Asia c. 1850-2000. Singapore: Institute of Southeast Asian Studies; 2004.

[39] Bogard JR, Farook S, Marks GC, Waid J, Belton B, Ali M, et al. Higher fish but lower micronutrient intakes: Temporal changes in fish consumption from capture fisheries and aquaculture in Bangladesh. PLoS ONE 2017; 12(4): e0175098.

https://doi.org/10.1371/journal.pone.0175098 
[40] Padilla JE, Mamauag S., Braganza G., Brucal N, Yu D., Morales A. 'Sustainability Assessment of the Live Reef-Fish for Food Industry in Palawan Philippines.' Quezon City: WWF-Philippines; 2003.

[41] Verité. Research on Indicators of Forced Labour in the Supply chain of tuna in the Philippines. https://www.verite.org/wp-content/uploads/2016/11/Research-on-Indicators-ofForced-Labor-in-the-Philippines-Tuna-Sector 9.16.pdf; 2016 (accessed 20/12/2017)

[42] Fabinyi M. 2012. Fishing for Fairness: Poverty, Morality and Marine Resource Regulation in the Philippines. Canberra: ANU Press; 2012.

[43] Blanc-Szanton MC. A Right to Survive: Subsistence Marketing in a Lowland Philippine Town. University Park (PA): Pennsylvania State University Press; 1972.

[44] Miller AMM, Bush SR, Mol APJ. Power Europe: EU and the illegal, unreported and unregulated tuna fisheries regulation in the West and Central Pacific Ocean. Mar. Policy $2014 ; 45,138-145$.

[45] Fabinyi M. Historical, Cultural and Social Perspectives on Luxury Seafood Consumption in China. Environmental Conservation 2012; 39(1): 83-92.

[46] Gutierrez NL, Defeo O, Bush SR, Butterworth DS, Roheim CA, Punt AE. The current situation and prospects of fisheries certification and ecolabelling. Fish. Res. 2016; 182:1-6.

[47] Ponte S. The Marine Stewardship Council (MSC) and the Making of a Market for 'Sustainable Fish'. Journal of Agrarian Change 2012; 12: 300-315.

[48] Scholtens J, Bavinck M. Oceans' contribution to food security of the poor: confronting ominous trends. Current Conservation 2017; 11(2): 3-8. 
[49] Ratner BD, Allison EH. Wealth, rights, and resilience: an agenda for governance reform in small-scale fisheries. Development Policy Review 2012; 30:371-398.

[50] Ruddle K, Davis A. Human rights and neo-liberalism in small-scale fisheries: Conjoined priorities and processes. Marine Policy 2013; 39:87-93.

[51] Song A. How to capture small-scale fisheries' many contributions to society?-

Introducing the 'value-contribution matrix' and applying it to the case of a swimming crab fishery in South Korea. In Johnson D, Acott TG, Stacey N, Urquhart J. Social Wellbeing and the Values of Small-scale Fisheries. Springer: Dordrecht; 2018.

[52] Song AM, Chuenpagdee R. Eliciting Values and Principles of Fishery Stakeholders in South Korea: A Methodological Exploration. Society \& Natural Resources 2015; 28(10): 1075-1091.

[53] Van Holt T, Weisman W, Johnson JC, Käll S, Whalen J, Spear B, Sousa P. A social wellbeing in fisheries tool (SWIFT) to help improve fisheries performance. Sustainability 2016; 8(8):667.

[54] Bailey M, Bush S, Oosterveer P, Larastiti L. Fishers, fair trade, and finding middle ground. Fisheries Research 2016; 182:59-68.

[55] Jentoft S, Chuenpagdee R, Barragán-Paladines MJ, Franz N. The Small-Scale Fisheries Guidelines: Global Implementation. Springer: Dordrecht; 2017.

[56] Kittinger JN, Teh LC, Allison EH, Bennett NJ, Crowder LB, Finkbeiner EM, Hicks C, Scarton CG, Nakamura K, Ota Y, Young J. Committing to socially responsible seafood. Science $2017 ; 356(6341): 912-3$. 
[57 Barrientos S, Gereffi G, Rossi A. Economic and social upgrading in global production networks: A new paradigm for a changing world. International Labour Review 2011; 150(3-4):319-40.

[58] Charles AT. Small-scale fisheries: on rights, trade and subsidies. Marit Stud 2011;10(2):85-94.

[59] von Moltke A (editor). Fisheries subsidies, Sustainable Development and the WTO. London and New York: Routledge; 2014.

[60] Sen A. Development as freedom (1st ed.). New York: Oxford University Press; 1999.

[61] Li TM. The Will to Improve: Governmentality, Development, and the Practice of Politics. Durham (NC): Duke University Press; 2007. 